OPEN ACCESS

Edited by:

Luis Eduardo Coelho Andrade, Federal University of São Paulo, Brazil

Reviewed by:

Narcisa Martinez Quiles, Complutense University of Madrid,

Spain

Marie-Agnes Dragon-Durey, Université Paris Descartes, France

*Correspondence:

Pier Luigi Meroni pierluigi.meroni@unimi.it

Specialty section: This article was submitted to Cytokines and Soluble Mediators in Immunity, a section of the journal Frontiers in Immunology

Received: 17 June 2021 Accepted: 01 September 2021 Published: 21 September 2021

Citation:

Meroni PL and Borghi MO (2021) Antiphospholipid Antibody Assays in 2021: Looking for a Predictive Value in Addition to a Diagnostic One.

Front. Immunol. 12:726820. doi: 10.3389/fimmu.2021.726820

\section{Antiphospholipid Antibody Assays in 2021: Looking for a Predictive Value in Addition to a Diagnostic One}

\author{
Pier Luigi Meroni ${ }^{1 *}$ and Maria Orietta Borghi ${ }^{1,2}$ \\ ${ }^{1}$ Istituto Auxologico Italiano, IRCCS, Immunorheumatology Research Laboratory, Milan, Italy, ${ }^{2}$ Department of Clinical \\ Science and Community Health, University of Milan, Milan, Italy
}

Antiphospholipid antibodies (aPL) are mandatory for the diagnosis but are also a risk factor for the antiphospholipid syndrome (APS) clinical manifestations. Lupus anticoagulant (LA), anticardiolipin (aCL), and anti-beta2 glycoprotein I ( $\left.\beta_{2} \mathrm{GPI}\right)$ assays are the formal laboratory classification/diagnostic criteria. Additional nonclassification assays have been suggested; among them, antiphosphatidylserine-prothrombin (aPS/ $\mathrm{PT}$ ) and antidomain $1 \beta_{2} \mathrm{GPI}$ antibodies are the most promising ones although not yet formally accepted. aPL represent the example of a laboratory test that moved from dichotomous to quantitative results consistent with the idea that reporting quantitative data offers more diagnostic/prognostic information for both vascular and obstetric manifestations. Although the general rule is that the higher the aPL titer, the higher the test likelihood ratio, there is growing evidence that this is not the case for persistent low titers and obstetric events. LA displays the highest diagnostic/prognostic power, although some isolated LAs are apparently not associated with APS manifestations. Moreover, isotype characterization is also critical since $\operatorname{lgG} \mathrm{aPL}$ are more diagnostic/prognostic than IgA or IgM. aPL are directed against two main autoantigens: $\beta_{2}$ GPI and PT. However, anti$\beta_{2}$ GPI antibodies are more associated with the APS clinical spectrum. In addition, there is evidence that anti- $\beta_{2}$ GPI domain 1 antibodies display a stronger diagnostic/prognostic value. This finding supports the view that antigen and even epitope characterization represents a further step for improving the assay value. The strategy to improve aPL laboratory characterization is a lesson that can be translated to other autoantibody assays in order to improve our diagnostic and prognostic power.

Keywords: thrombosis, miscarriages, antiphospholipid antibodies, $\beta_{2}$-glycoprotein I, prothrombin

\section{INTRODUCTION}

The antiphospholipid syndrome (APS) is formally defined as the association of arterial/venous thrombosis and/or recurrent miscarriages in the absence of any other known cause and the persistent presence of antiphospholipid antibodies (aPL) detectable by solid-phase (beta2 glycoprotein I [ $\beta 2 \mathrm{GPI}$-dependent anticardiolipin [CL] and anti- $\beta 2 \mathrm{GPI})$ or functional coagulation assays (lupus anticoagulant-LA) (Table 1) (1). Additional laboratory diagnostic tests have been suggested, but their formal inclusion in the classification tools is still a matter of 
TABLE 1 | Classification and nonclassification laboratory aPL assays.

\begin{tabular}{|c|c|c|}
\hline Target $\mathbf{A g}$ & $\begin{array}{l}\text { Plates coated with/biological } \\
\text { material used }\end{array}$ & $\begin{array}{c}\text { Technical characteristics of the assay and } \\
\text { type of detectable antibodies }\end{array}$ \\
\hline Bovine $\beta_{2} \mathrm{GPI}$ & Anionic PL & aCL solid phase assay \\
\hline Human $\beta_{2} \mathrm{GPI}$ & $\gamma$-irradiated plates & Anti- $\beta_{2}$ GPI solid phase assay \\
\hline Human $\beta_{2} \mathrm{GPI} /$ Domain I/Domain I peptide & Hydrophobic/hydrophilic or $\gamma$-irradiated plates & Anti-DI $\beta 2$ GPI solid phase assay \\
\hline Human PT & Anionic PL (PS) & $\begin{array}{l}\text { Anti-PT/anti-PS/PT } \\
\text { solid phase assay }\end{array}$ \\
\hline $\begin{array}{l}\text { Protein C, Protein S } \\
\text { and C4b-binding protein } \\
\text { Activated Protein C } \\
\text { Thrombomodulin }\end{array}$ & Anionic PL & Mostly anti- $\beta 2 \mathrm{GPI}$ antibodies \\
\hline Annexin $\mathrm{V}$ & Anionic PL & Mostly anti- $\beta 2 \mathrm{GPI}$ antibodies \\
\hline High molecular weight kininogen & Neutral PL (PE) & Anti-PE solid phase assay \\
\hline Human $\beta_{2} \mathrm{GPI} / \mathrm{PT}$ & Human plasma & LA: functional PL-dependent coagulation assay \\
\hline
\end{tabular}

$\beta_{2} G P I$, beta2 glycoprotein I; PL, phospholipids; aCL, anticardiolipin antibodies; PT, prothrombin; PS, phosphatidylserine; PE, phosphatidylethanolamine; LA, lupus anticoagulant.

debate (Table 1) $(1,2)$. The detection of aPL represents a milestone in the diagnosis of APS despite the still debated description of rare seronegative APS in which the clinical manifestations are resembling the full-blown syndrome, but the serological assays are negative (3).

There is strong evidence that aPL, rather than being a mere diagnostic tool, display a direct pathogenic role through complement-fixing antibodies in animal models (4). Medium/ high titers of aPL detectable by solid-phase assays (i.e., aCL and anti- $\beta 2$ GPI) or the positivity for two or three laboratory assays confer a higher risk for both vascular and obstetric events than low titer aPL or positivity in a single test only $(5,6)$. Preliminary studies raised the issue of whether abnormalities in serum complement levels can be predictive for a poor pregnancy outcome, but confirmatory studies are still needed and to be extended to vascular APS $(7,8)$. So, aPL are emerging as a risk factor, and their high likelihood ratio/predictive value is becoming more and more important. This is actually in line with the similar need reported for other autoantibodies in systemic autoimmune rheumatic diseases (SARD) $(9,10)$.

How to interpret the aPL assays correctly and which assays should be requested for the best diagnostic/prognostic strategy are the main questions that will be addressed in the present minireview to offer a state-of-the-art of aPL testing in 2021.

\section{LABORATORY PERSPECTIVES}

\section{Autoantibodies in Diagnostic and Classification Criteria for APS}

The three aPL assays (i.e., $\beta 2 \mathrm{GPI}-$ dependent aCL, anti- $\beta 2 \mathrm{GPI}$, and LA) are the formal classification laboratory tests that are also commonly used for diagnostic purposes (1).

In 1990, three different groups reported that aPL do not recognize anionic PL alone but bound to a PL-binding glycoprotein, later identified as $\beta 2$ GPI (11-13). The anti$\beta 2 \mathrm{GPI}$ antibodies bind their antigen either when complexed with CL in the presence of a source of $\beta 2 \mathrm{GPI}$ in CL-coated plates or directly in $\beta 2 \mathrm{GPI}$-coated plates. It has been suggested that once bound to CL, $\beta 2$ GPI displays conformational changes and/ or increases its antigenic density so favoring antibody binding (5, $14)$. On the other hand, $\beta 2 \mathrm{GPI}$ coating to $\gamma$-irradiated polystyrene plates is thought to reproduce similar molecule presentation ultimately offering the right antigen structure to the antibodies $(5,14)$. In other words, $\beta 2$ GPI-dependent antibodies are responsible for positive results in the two solidphase assays that are the formal laboratory classification criteria for APS, namely aCL and anti- $\beta 2 \mathrm{GPI}$ antibody tests.

The term "lupus anticoagulant" (LA) refers to a panel of different functional assays detecting a heterogeneous group of immunoglobulins behaving as acquired in vitro inhibitors of the coagulation. LA detection is based on PL-dependent coagulation tests requiring complex methods. The interpretation of the results is difficult owing to interfering factors, such as anticoagulant drugs and acute phase proteins leading to false-positive results (15-17). The International Society of Thrombosis and Haemostasis has recently provided the updated guidelines for LA detection/ interpretation (18). Anti- $\beta_{2}$ GPI antibodies have been shown to prolong the PL-dependent coagulation tests and were thought to be responsible in part for the so-called LA phenomenon (19-21). This finding supports the idea that $\beta_{2}$ GPI-dependent aPL can be responsible for the positivities in all the three formal laboratory classification (and diagnostic) tests for APS. On the other hand, antibodies against prothrombin (aPT) and in particular those reacting with the phosphatidylserine (PS)-PT complex (aPS/PT) have been also shown to mediate the LA phenomenon (22-24). Finally, "isolated" LA without any anti- $\beta_{2}$ GPI or aPS/PT antibodies has been described. In these samples, the coagulation inhibitors (antibodies)? are still a matter of research $(25,26)$.

\section{Nonclassification Laboratory Criteria}

Although both IgG and IgM aPL have been included in the laboratory classification criteria (1), the IgG isotype has displayed a higher diagnostic and prognostic value than the IgM one for both the vascular and the obstetric manifestations of the syndrome since the beginning of the APS story $(27,28)$. More recently, several groups suggested that IgA aPL may offer a good diagnostic/prognostic profile as well. This was the case in patients with clinical manifestations suggestive for APS but 
negative for aCL/anti- $\beta 2$ GPI IgG or IgM or LA (29-33). In particular, IgA aCL/anti- $\beta_{2}$ GPI positivities were reported in systemic lupus erythematosus (SLE) patients with associated APS (29-32). Therefore, the detection of IgA aPL is becoming more and more popular in the diagnostic algorithm for APS. However, IgA aPL are not formally included in the laboratory classification criteria yet (32).

The conformational modifications of the $\beta 2 \mathrm{GPI}$ are in line with the theory that most of the $\beta 2 \mathrm{GPI}-$ dependent aPL recognize an immunodominant epitope located in the domain (D) 1 of the molecule. It has been suggested that $\beta 2 \mathrm{GPI}$, once bound to anionic surfaces, undergoes structural changes making the D1 more available for the antibodies $(14,34)$. There is sound evidence that anti-D1 antibodies mediate pathogenic mechanisms in experimental models and support clotting and fetal loss in animal models (35-37). Moreover, clinical studies clearly showed that the presence of anti-D1 $\beta 2$ GPI IgG displays a higher specificity and predictive value than IgG against the whole molecule (38-41). Accordingly, anti-D1 detection has been suggested as a new laboratory criterion for APS $(32,42)$. However, up to $20 \%$ of the patients positive for antibodies against the whole $\beta 2 \mathrm{GPI}$ molecule can test negative for specific anti-D1 assays (32). As a consequence, the idea to replace the whole molecule solid-phase assay with the test for anti-D1 has not been accepted yet. However, the presence of antibodies against D1 has been suggested to be a sort of a confirmatory test for aPL specifically associated with APS. For example, anti-D1 antibodies are not usually detected in aPL present during infectious diseases $(43,44)$ or in other conditions unrelated to APS, such as in children with atopic dermatitis or babies born from mothers with non-APS autoimmune disorders (38).

Antibodies against linear epitopes of other $\beta 2 \mathrm{GPI}$ domains have been reported, but clear associations with specific clinical manifestations of the syndrome were not found (45). However, antibodies against a D4-5 conformational complex have been recently investigated in a deeper manner. These antibodies have been mostly detected in non-APS patients such as patients with aPL and concomitant infectious disease or in children suffering from atopic dermatitis or in babies born from mothers with $\operatorname{SARD}(38,40,41,43,44)$. Polyclonal IgG from subjects/patients positive for isolated anti- $\beta 2$ GPI $D 4,5$ antibodies were not able to trigger thrombosis in naiivve rats at variance with anti-D1 polyclonal IgG that were thrombogenic in the same model (35).

Moreover, higher titers and prevalence of anti-D4,5 IgG were found in asymptomatic aPL-positive carriers $(40,41)$. Altogether these data strongly support the idea that anti-D4,5 antibodies are not pathogenic and not diagnostic for APS (46). Interestingly, anti-D4,5 antibodies mainly recognize D5 and react with $\beta 2 \mathrm{GPI}$ free in solution or with the molecule bound to $\gamma$-irradiated polystyrene plates but not with $\beta 2$ GPI bound to CL. Since D5 is located in the PL-binding site of $\beta 2 \mathrm{GPI}$, it has been suggested that D5 is available when the molecule is free in solution or when the coating to the plates does not involve the PL-binding site. The engagement of D5 in the PL-binding site (e.g., through CL) would be responsible for a steric hindrance and ultimately for the lack of reactivity of the anti-D5 antibodies (35).
As stated before, the LA phenomenon can be also mediated by aPT antibodies. Solid- phase assays with a matrix coated with PT were set up and aPT antibodies were detected. However, these antibodies did not display a good diagnostic or predictive value for the APS clinical manifestations $(47,48)$. On the other hand, when PT binds to PS-coated plates in the presence of Ca ions, it displays a right conformational change and can be recognized by aPS/PT antibodies. These antibodies have been found associated with APS, and their presence may increase the diagnostic/prognostic value of the other antibodies (e.g., aCL/anti- $\beta 2 \mathrm{GPI}$ and LA) (48). This is the case of the so-called tetrapositive patients (49). While aPS/PT have been reported in vascular APS, their association with the obstetric manifestations is still a matter of research (50-52). So, the inclusion of aPS/PT antibodies into the formal laboratory classification criteria has not been formally accepted up to now (32). Since aPS/PT antibodies were found to be associated with LA, some authors suggested their use as a surrogate test for LA when the interference of the concomitant anticoagulant therapy cannot allow performing the functional assays in a reliable manner (53). While the debate to include aPS/PT antibodies into the laboratory classification criteria is open, the experimental evidence for a direct pathogenic role for aPS/PT is not as sound as that reported for the anti- $\beta 2 \mathrm{GPI}$ antibodies $(2,5)$.

Other anionic PL, such as PS or phosphatidic acid (PA) or phosphatidylinositol (PI), have been used to coat the matrix in order to substitute CL in alternative solid-phase assays. Once again, $\beta 2 \mathrm{GPI}$, as a cationic molecule, forms a complex with the anionic PL and eventually offers similar antigenic targets for the antibodies. Accordingly, even PS- or PI- or PA-coated plates are actually detecting $\beta 2 \mathrm{GPI}$-dependent antibodies, and there is no sound evidence that they offer further diagnostic information $(5,54)$.

Additional tests have been reported in the literature to detect antibodies directed against serum proteins that bind to anionic surfaces, such as Annexin V, Protein C (activated Protein C), and Protein S. All these tests are actually detecting antibodies against $\beta 2 \mathrm{GPI}$, so it is not clear whether or not they are offering more diagnostic/prognostic information in comparison with the $\beta 2$ GPI assay itself $(5,55-58)$. Antibodies directed against high molecular weight kininogen bound to neutral PL such as phosphatidylethanolamine (PE) have been reported, but their usefulness is limited to a handful of cases with clinical manifestations similar to those present in APS (59).

\section{Standardization of aPL Assays}

The comparability in performing and the uniformity in interpreting test results in the diagnostic algorithms for autoimmune diseases are hot issues because of the lack of harmonization despite their increasing use and the development of new techniques $(9,60)$. The same problem has been raised in APS given the huge variability of aPL results reported at the beginning of the APS story. The switch from enzymatic or fluorimetric solid-phase assays to chemiluminescent techniques improved the sensitivity without affecting the specificity and at the same time offering more reproducibility. Ultimately, the aPL detection methods available nowadays offer more reproducible results and allow harmonization as recently shown in a large 
multicenter study (61). Still, we have some unmet needs in the field of aPL testing. For example, the high sensitivity of the new assays raised the issue of a wide range of borderline results formally higher than the cutoff of healthy subjects but with doubtful clinical significance. A critical interpretation of the real diagnostic/prognostic value of borderline results is strongly recommended in the clinical setting, and operators are invited to perform their own cutoff values. While there is a general agreement that only medium/high aPL titers in the solid-phase assays should be taken into account to support the diagnosis of vascular APS, recent evidence is supporting the usefulness of low titer aPL in the obstetric variant (62).

As in the case of many other laboratory diagnostic tests for autoimmune diseases, we do not have international standards to express the test results in international units. However, the Committee on Harmonization of Autoimmune Testing of the International Federation of Clinical Chemistry and Laboratory Medicine in collaboration with the Joint Research Institute of the European Commission has studied the possibility of developing a certified reference material (CRM) with an assigned property value (anti- $\beta 2$ GPI IgG antibodies concentration in a matrix material). The availability of such CRM should offer the possibility to express the results in absolute values further improving the harmonization of aPL testing (63).

\section{CLINICAL PERSPECTIVES}

\section{Clinical Significance for Vascular APS}

As stated before, aPL are now generally accepted as a risk factor for the clinical manifestations of the syndrome. In particular, the probability of thrombotic recurrences in the vascular APS is correlated with the aPL titer, being medium/high antibody levels associated with arterial/venous events much more than low titers. Moreover, the simultaneous positivity for two or three classification laboratory tests is an additional risk factor for recurrences. More recently, it has been suggested that the presence of aPS/PT antibodies in addition to the three laboratory classification criteria (i.e., LA, aCL, anti- $\beta 2 \mathrm{GPI}$ ) represents a further risk factor in the socalled tetrapositive patients $(6,49)$.

Antiphospholipid antibodies of the IgG Isotype display a more predictive value for the vascular manifestations in comparison with IgM. There is growing evidence that IgA aPL can be more predictive for vascular events than IgM as well; however, more data should support this statement $(30,31,64)$.

Among the three formal classification laboratory assays, LA is widely considered the most predictive one, even if isolated LA positive cases can be found not associated with any vascular events $(26,49,65,66)$. The high predictive value of LA was related to the presence of both anti- $\beta 2 \mathrm{GPI}$ and aPS/PT antibodies in most of the LA positive samples (24, 67-69). Moreover, as a functional coagulation assay, LA displays a lower sensitivity compared with the solid-phase assays in detecting the same amount of autoantibodies. So, the higher aPL titers needed for altering the coagulation assay could justify the stronger predictive power for the clinical manifestations in both the full-blown APS and in the aPL-positive asymptomatic carriers.
Isolated aCL positive results, in particular at medium/low titer, are more frequently reported than isolated anti- $\beta 2 \mathrm{GPI}$ in non-APS conditions such as during concomitant infectious diseases. Their clinical significance is doubtful and should be evaluated in a specific clinical setting.

As shown in Figure 1A, the whole risk profile for the vascular APS is supported not only by the aPL profile (e.g., titer, isotype, type of the detection assay) but also by aPL-unrelated variables such as traditional cardiovascular risk factors and the presence of an associated underlying SARD. In particular, the association with a systemic inflammatory disease may offer a significant trigger according to the two-hit hypothesis for APS (5).

\section{Clinical Significance for Obstetric APS}

Medium/high aPL titers and double or triple positivity for the classification laboratory criteria do represent the major risk factor for the obstetric manifestations of APS as for the vascular ones. However, it has been suggested that even low aPL titers can display a prognostic value for recurrent miscarriages $(62,70,71)$. This issue has been addressed recently by a large monocentric study that showed how the positivity for aCL and anti- $\beta 2 \mathrm{GPI}$, if persistent over time and associated, may be predictive for miscarriages. The finding is also important from a clinical point of view since all the low titer pregnant women were responsive to the standard therapy with the combination of LDASA and LMWH at variance with patients with medium/high aPL titers who display recurrences in up to $20 \%$ of the cases (62). The demonstration of the huge presence of $\beta 2 \mathrm{GPI}$ in the placenta, even in physiological conditions, could explain why low aPL titers may be enough for displaying their pathogenic effect. This is not the case for $\beta 2 \mathrm{GPI}$ on the vessel walls in resting conditions where the aPL target antigen cannot be found unless an endothelial perturbation is taking place. The lower presence of $\beta 2 \mathrm{GPI}$ on the vessels could explain, on the other hand, why much higher amounts of aPL are needed for triggering the clot $(71,72)$.

A similar higher risk profile of the IgG than IgM isotype for $\mathrm{aCL}$ and anti- $\beta 2 \mathrm{GPI}$ assays and the more predictive value of isolated LA in comparison with isolated aCL or anti- $\beta 2 \mathrm{GPI}$ test have been reported for the recurrent miscarriages as well $(41,70)$.

As for vascular APS, the whole risk profile for obstetric variant should take into consideration additional aPL-unrelated risk factors such as the previous obstetric history and/or the presence of an underlying systemic autoimmune inflammatory disorder (Figure 1B) (71).

\section{Asymptomatic aPL-Positive Carriers}

As discussed before for patients with both the full-blown vascular and obstetric syndrome, the aPL profile is crucial to characterize the risk for APS manifestations even in subjects with positive aPL but without any previous thrombotic event or miscarriage: the so-called asymptomatic aPL-positive carriers. The risk of these subjects for developing clinical events is likely similar to that in APS patients, but there are a few ad hoc prospective studies to support it in a formal way $(26,73)$. In summary, the presence of a double or triple positivity for the classification laboratory criteria, the medium/high aPL titer in the solid-phase assays, the positivity 
A

\section{Vascular APS}

aPL autoAb profile

Test

Triple positivity

LA

Isotype

Titer

$\lg G>\lg M$

Medium/high titer

$\checkmark$ Concomitant thrombotic risk-factors

$\checkmark \quad$ Underlying autoimmune diseases

\section{B Obstetric APS}

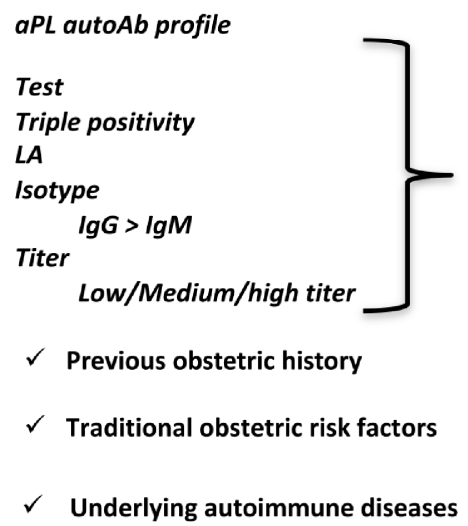

Higher risk

Age, diabetes, arterial hypertension, dyslipidemia, BMI, smoking, sedentary lifestyle, hyperhomocysteinemia, Protein C, Protein S and ATIII deficiency, Factor V Leiden, PT and MHTFR.

Higher risk

Age, diabetes, arterial hypertension, dyslipidemia,

BMI, smoking, sedentary lifestyle etc.

FIGURE 1 | Antiphospholipid antibodies as a risk factor. aPL profile, isotype, titer, and aPL-unrelated factors defining higher risk for (A) vascular APS and (B) obstetric APS.

for IgG/IgA versus IgM antibodies, and the epitope specificity for D1 of anti- $\beta 2$ GPI are the parameters useful for risk stratification.

The presence of aPL-unrelated traditional cardiovascular or obstetric risk factors can play an additional role in the risk profile as also previously discussed for APS patients (Figure 1). Unfortunately, we still do not have sound information on which type of therapeutic intervention is the best to prevent clinical manifestations. Ad hoc clinical trials should be carried out.

\section{Is There a Value of Repeated Autoantibody Testing in Symptomatic At-Risk Patients?}

Antiphospholipid antibodies are persistent over time according to the classification criteria of the syndrome (1). There is no sound evidence that they can fluctuate for example during an acute thrombotic event or during pregnancy. In this regard, aPL are quite similar to other autoantibodies detectable in SARD, such as rheumatoid factor, anticitrullinate peptide antibodies, or antibodies against extractable nuclear antigens. Nevertheless, a decrease in the aPL titer has been reported in some cases during a long follow-up, especially in patients receiving treatment with antimalarials (hydroxychloroquine) and/or anti-B cell therapy (anti-Blys monoclonal antibody) (74-76). On the other hand, transient positivities are usually described for aPL detectable in non-APS conditions, in particular during infectious diseases (77). As a consequence, repeated aPL testing is suggested for confirming the positivity and to support the suspect that the antibodies are related to a concomitant infectious disease but not for monitoring the classical APS.

\section{DISCUSSION}

The right choice and interpretation of the diagnostic aPL assays are pivotal to avoid the risk of an overdiagnosis, having in mind that both thrombosis and miscarriages are relatively frequent and due to several causes unrelated to aPL. For example, low aPL titers, isolated positivities in one single laboratory test, as well as transient positivities should be critically evaluated. Anti- $\beta 2$ GPI antibodies with $\mathrm{D} 4,5$ specificity are positive in the anti- $\beta 2 \mathrm{GPI}$ but negative in the aCL assay as reported previously. These 
antibodies are not associated with APS manifestations and are not pathogenic in animal models; altogether this finding supports that they are not diagnostic aPL (35). Another example is represented by isolated LA positivities in patients under heparin or oral anticoagulation that can affect the reproducibility of the test. High levels of $\mathrm{C}$ reactive protein have been also associated with false LA results, especially in patients during acute illness (15-17). So, positive LA tests in these conditions should be critically evaluated before making a final diagnosis. The use of solid-phase assays for antibodies potentially responsible for LA, such as $\beta 2 \mathrm{GPI}$ and aPS/PT, could help since the solid-phase assays are not affected by the variables responsible for false-positive functional tests (61).

Nonclassification laboratory tests such as antidomain assays or the test for aPS/PT could help in ruling out or in supporting the diagnosis of APS. For example, the lack of reactivity against D1 in a single positive anti- $\beta 2$ GPI patient or the negativity for $\mathrm{aPS} / \mathrm{PT}$ in an isolated LA during anticoagulation cast doubts on the real presence of an APS. The strategy of using a panel of biomarkers (e.g., different autoantibodies) is becoming more and

\section{REFERENCES}

1. Miyakis S, Lockshin MD, Atsumi T, Branch DW, Brey RL, Cervera R, et al. International Consensus Statement on an Update of the Classification Criteria for Definite Antiphospholipid Syndrome (APS). J Thromb Haemost (2006) 4:295-306. doi: 10.1111/j.1538-7836.2006.01753.x

2. Meroni PL, Chighizola CB, Rovelli F, Gerosa M. Antiphospholipid Syndrome in 2014: More Clinical Manifestations, Novel Pathogenic Players and Emerging Biomarkers. Arthritis Res Ther (2014) 16:209. doi: 10.1186/ar4549

3. Pignatelli P, Ettorre E, Menichelli D, Pani A, Violi F, Pastori D. Seronegative Antiphospholipid Syndrome: Refining the Value of "Non-Criteria" Antibodies for Diagnosis and Clinical Management. Haematologica (2020) 105:562-72. doi: 10.3324/haematol.2019.221945

4. Fischetti F, Durigutto P, Pellis V, Debeus A, Macor P, Bulla R, et al. Thrombus Formation Induced by Antibodies to Beta2-Glycoprotein I Is Complement Dependent and Requires a Priming Factor. Blood (2005) 106:2340-6. doi: 10.1182/blood-2005-03-1319

5. Meroni PL, Borghi MO, Raschi E, Tedesco F. Pathogenesis of Antiphospholipid Syndrome: Understanding the Antibodies. Nat Rev Rheumatol (2011) 7:330-9. doi: 10.1038/nrrheum.2011.52

6. Pengo V, Ruffatti A, Legnani C, Gresele P, Barcellona D, Erba N, et al. Clinical Course of High-Risk Patients Diagnosed With Antiphospholipid Syndrome. J Thromb Haemost (2010) 8:237-42. doi: 10.1111/j.1538-7836.2009.03674.x

7. Kim MY, Guerra MM, Kaplowitz E, A Laskin C, Petri M, Branch DW, et al. Complement Activation Predicts Adverse Pregnancy Outcome in Patients With Systemic Lupus Erythematosus and/or Antiphospholipid Antibodies. Ann Rheumatol Dis (2018) 77:549-55. doi: 10.1136/annrheumdis-2017-212224

8. Nalli C, Lini D, Andreoli L, Crisafulli F, Fredi M, Lazzaroni MG, et al. Low Preconception Complement Levels Are Associated With Adverse Pregnancy Outcomes in a Multicenter Study of 260 Pregnancies in 197 Women With Antiphospholipid Syndrome or Carriers of Antiphospholipid Antibodies. Biomedicines (2021) 9:671. doi: 10.3390/biomedicines9060671

9. Bossuyt X, De Langhe E, Borghi MO, Meroni PL. Understanding and Interpreting Antinuclear Antibody Tests in Systemic Rheumatic Diseases. Nat Rev Rheumatol (2020) 16:715-26. doi: 10.1038/s41584-020-00522-w

10. Rönnelid J, Turesson C, Kastbom A. Autoantibodies in Rheumatoid Arthritis - Laboratory and Clinical Perspectives. Front Immunol (2021) 12:685312. doi: 10.3389/fimmu.2021.685312

11. McNeil HP, Simpson RJ, Chesterman CN, Krilis SA. Anti-Phospholipid Antibodies Are Directed Against a Complex Antigen That Includes a LipidBinding Inhibitor of Coagulation: Beta 2-Glycoprotein I (Apolipoprotein H). Proc Natl Acad Sci USA (1990) 87:4120-4. doi: 10.1073/pnas.87.11.4120 more popular in APS as well as in other autoimmune diseases and meets the need of precision medicine in this setting.

\section{AUTHOR CONTRIBUTIONS}

PM drafted the text and MB contributed to the article. Both authors revised and approved the manuscript.

\section{FUNDING}

The study was supported in part by Ricerca Finalizzata, Ministero Salute 2020 to PM.

\section{ACKNOWLEDGMENTS}

The authors thank Dr. Paola A. Lonati for her support in the figure preparation.

12. Galli M, Barbui T, Comfurius P, Maassen C, Hemker HC, Zwaal RFA, et al Anticardiolipin Antibodies (ACA) Directed Not to Cardiolipin But to a Plasma Protein Cofactor. Lancet (1990) 335:1544-7. doi: 10.1016/0140-6736(90)91374-j

13. Matsuura E, Igarashi Y, Fujimoto M, Ichikawa K, Koike T. Anticardiolipin Cofactor(s) and Differential Diagnosis of Autoimmune Disease. Lancet (1990) 336:177-8. doi: 10.1016/0140-6736(90)91697-9

14. de Laat B, Derksen RH, van Lummel M, Pennings MT, de Groot PG. Pathogenic Anti-Beta2-Glycoprotein I Antibodies Recognize Domain I of Beta2-Glycoprotein I Only After a Conformational Change. Blood (2006) 107:1916-24. doi: 10.1182/blood-2005-05-1943

15. Martinuzzo ME, Barrera LH, D 'Adamo MA, Otaso JC, Gimenez MI, Oyhamburu J. Frequent False-Positive Results of Lupus Anticoagulant Tests in Plasmas of Patients Receiving the New Oral Anticoagulants and Enoxaparin. Int J Lab Hematol (2014) 36:144-50. doi: 10.1111/ijlh.12138

16. Schouwers SME, Delanghe JR, Devreese KMJ. Lupus Anticoagulant (LAC) Testing in Patients With Inflammatory Status: Does C-Reactive Protein Interfere With LAC Test Results? Thromb Res (2010) 125:102-4. doi: 10.1016/ j.thromres.2009.09.001

17. Ruinemans-Koerts J, Ahmed-Ousenkova YM, Kaasjager HAH, Hendriks-van Wijhe C, Hovens MMC. When to Screen for Lupus Anticoagulant? Influence of Testing During Acute Phase and Consequences for Clinical Practise. Lupus (2015) 24:1233-5. doi: 10.1177/0961203315583540

18. Devreese KMJ, de Groot PG, de Laat B, Erkan D, Favaloro EJ, Mackie I, et al. Guidance From the Scientific and Standardization Committee for Lupus Anticoagulant/Antiphospholipid Antibodies of the International Society on Thrombosis and Haemostasis: Update of the Guidelines for Lupus Anticoagulant Detection and Interpretation. J Thromb Haemost (2020) 18:2828-39. doi: $10.1111 /$ jth.15047

19. Dienava-Verdoold I, Boon-Spijker MG, de Groot PG, Brinkman HJ, Voorberg J, Mertens K, et al. Patient-Derived Monoclonal Antibodies Directed Towards Beta2 Glycoprotein-1 Display Lupus Anticoagulant Activity. J Thromb Haemost (2011) 9:738-47. doi: 10.1111/j.1538-7836.2011.04212.x

20. Lai CJ, Rauch J, Cho CS, Zhao Y, Chukwuocha RU, Chen PP. Immunological and Molecular Analysis of Three Monoclonal Lupus Anticoagulant Antibodies From a Patient With Systemic Lupus Erythematosus. J Autoimmun (1998) 11:39-51. doi: 10.1006/jaut.1997.0174

21. Arnout J, Vanrusselt M, Wittevrongel C, Vermylen J. Monoclonal Antibodies Against Beta-2-Glycoprotein I: Use as Reference Material for Lupus Anticoagulant Tests. Thromb Haemost (1998) 79:955-8. doi: 10.1055/s0037-1615101

22. Molhoek JE, de Groot PG, Urbanus RT. The Lupus Anticoagulant Paradox. Semin Thromb Hemost (2018) 44:445-52. doi: 10.1055/s-0037-1606190 
23. Pengo V, Del Ross T, Ruffatti A, Bison E, Cattini MG, Pontara E, et al. Lupus Anticoagulant Identifies Two Distinct Groups of Patients With Different Antibody Patterns. Thromb Res (2018) 172:172-8. doi: 10.1016/j.thromres.2018.11.003

24. Noordermeer T, Molhoek JE, Schutgens REG, Sebastian SAE, Drost-Verhoef $S$, van Wesel ACW, et al. Anti- 32 -Glycoprotein I and Anti-Prothrombin Antibodies Cause Lupus Anticoagulant Through Different Mechanisms of Action. J Thromb Haemost (2021) 19:1018-28. doi: 10.1111/jth.15241

25. Oosting JD, Ronald HWM, Derksen RH, Bobbink IW, Hackeng TM, Bouma BN, et al. Antiphospholipid Antibodies Directed Against a Combination of Phospholipids With Prothrombin, Protein C, or Protein S: An Explanation for Their Pathogenic Mechanism? Blood (1993) 81:2618-25. doi: 10.1182/ blood.V81.10.2618.2618

26. Pengo V, Testa S, Martinelli I, Ghirarduzzi A, Legnani C, Gresele P, et al. Incidence of a First Thromboembolic Event in Carriers of Isolated Lupus Anticoagulant. Thromb Res (2015) 135(1):46-9. doi: 10.1016/j.thromres. 2014.10.013

27. Gharavi AE, Harris EN, Asherson RA, Hughes GR. Anticardiolipin Antibodies: Isotype Distribution and Phospholipid Specificity. Ann Rheumatol Dis (1987) 46:1-6. doi: 10.1136/ard.46.1.1

28. Devreese KMJ. How to Interpret Antiphospholipid Laboratory Tests. Curr Rheumatol Rep (2020) 22:38. doi: 10.1007/s11926-020-00916-5

29. Cousins L, Pericleous C, Khamashta M, Bertolaccini ML, Ioannou Y, Giles I, et al. Antibodies to Domain I of $\beta$-2-Glycoprotein I and IgA Antiphospholipid Antibodies in Patients With 'Seronegative' Antiphospholipid Syndrome. Ann Rheumatol Dis (2015) 74:317-9. doi: 10.1136/annrheumdis-2014-206483

30. Pérez D, Tincani A, Serrano M, Shoenfeld Y, Serrano A. Antiphospholipid Syndrome and IgA Anti-Beta2-Glycoprotein I Antibodies: When Cinderella Becomes a Princess. Lupus (2018) 27:177-8. doi: 10.1177/0961203317738227

31. Andreoli L, Fredi M, Nalli C, Piantoni S, Reggia R, Dall'Ara F, et al. Clinical Significance of IgA Anti-Cardiolipin and IgA Anti- $\beta 2$ glycoprotein I Antibodies. Curr Rheumatol Rep (2013) 15:343. doi: 10.1007/s11926-0130343-1

32. Bertolaccini ML, Amengual O, Andreoli L, Atsumi T, Chighizola CB, Forastiero R, et al. 14th International Congress on Antiphospholipid Antibodies Task Force. Report on Antiphospholipid Syndrome Laboratory Diagnostics and Trends. Autoimmun Rev (2014) 13:917-30. doi: 10.1016/ j.autrev.2014.05.001

33. Tortosa C, Cabrera-Marante O, Serrano M, Martínez-Flores JA, Pérez D, Lora $\mathrm{D}$, et al. Incidence of Thromboembolic Events in Asymptomatic Carriers of IgA Anti ß2 Glycoprotein-I Antibodies. PloS One (2017) 12:e0178889. doi: 10.1371/journal.pone.0178889

34. Pericleous C, Miles J, Esposito D, Garza-Garcia A, Driscoll PC, Lambrianides A, et al. Evaluating the Conformation of Recombinant Domain I of $\beta(2)$ Glycoprotein I and Its Interaction With Human Monoclonal Antibodies. Mol Immunol (2011) 49:56-63. doi: 10.1016/j.molimm.2011.07.024

35. Durigutto P, Grossi C, Borghi MO, Macor P, Pregnolato F, Raschi E, et al. New Insight Into Antiphospholipid Syndrome: Antibodies to $\beta 2$ glycoprotein I-Domain 5 Fail to Induce Thrombi in Rats. Haematologica (2019) 104:81926. doi: 10.3324/haematol.2018.198119

36. Meroni PL, Macor P, Durigutto P, De Maso L, Gerosa M, Ferraresso M, et al. Complement Activation in Antiphospholipid Syndrome and Its Inhibition to Prevent Rethrombosis After Arterial Surgery. Blood (2016) 127:365-7. doi: 10.1182/blood-2015-09-672139

37. Agostinis C, Durigutto P, Sblattero D, Borghi MO, Grossi C, Guida F, et al. A Non-Complement-Fixing Antibody to $\beta 2$ Glycoprotein I as a Novel Therapy for Antiphospholipid Syndrome. Blood (2014) 123:3478-87. doi: 10.1182/ blood-2013-11-537704

38. Andreoli L, Nalli C, Motta M, Norman GL, Shums Z, Encabo S, et al. Anti- $\beta_{2^{-}}$ Glycoprotein I IgG Antibodies From 1-Year-Old Healthy Children Born to Mothers With Systemic Autoimmune Diseases Preferentially Target Domain 4/5: Might it be the Reason for Their 'Innocent' Profile? Ann Rheumatol Dis (2011) 70:380-3. doi: 10.1136/ard.2010.137281

39. de Laat B, de Groot PG. Autoantibodies Directed Against Domain I of Beta2Glycoprotein I. Curr Rheumatol Rep (2011) 13:70-6. doi: 10.1007/s11926010-0144-8

40. Andreoli L, Chighizola CB, Nalli C, Gerosa M, Borghi MO, Pregnolato F, et al. Clinical Characterization of Antiphospholipid Syndrome by Detection of IgG Antibodies Against $\beta 2$-Glycoprotein I Domain 1 and Domain 4/5: Ratio of
Anti-Domain 1 to Anti-Domain $4 / 5$ as a Useful New Biomarker for Antiphospholipid Syndrome. Arthritis Rheumatol (2015) 67:2196-204. doi: 10.1002/art.39187

41. Chighizola CB, Pregnolato F, Andreoli L, Bodio C, Cesana L, Comerio C, et al. Beyond Thrombosis: Anti- $\beta 2$ gpi Domain 1 Antibodies Identify Late Pregnancy Morbidity in Anti-Phospholipid Syndrome. J Autoimmun (2018) 90:76-83. doi: 10.1016/j.jaut.2018.02.002

42. Radin M, Cecchi I, Roccatello D, Meroni PL, Sciascia S. Prevalence and Thrombotic Risk Assessment of Anti- 32 Glycoprotein I Domain I Antibodies: A Systematic Review. Semin Thromb Hemost (2018) 44:466-74. doi: 10.1055/ s-0037-1603936

43. Borghi MO, Beltagy A, Garrafa E, Curreli D, Cecchini G, Bodio C, et al. AntiPhospholipid Antibodies in COVID-19 Are Different From Those Detectable in the Anti-Phospholipid Syndrome. Front Immunol (2020) 11:584241. doi: 10.3389/fimmu.2020.584241

44. Roggenbuck D, Borghi MO, Somma V, Büttner T, Schierack P, Hanack K, et al. Antiphospholipid Antibodies Detected by Line Immunoassay Differentiate Among Patients With Antiphospholipid Syndrome, With Infections and Asymptomatic Carriers. Arthritis Res Ther (2016) 18:111. doi: 10.1186/s13075-016-1018-x

45. Shoenfeld Y, Krause I, Kvapil F, Sulkes J, Lev S, von Landenberg P, et al. Prevalence and Clinical Correlations of Antibodies Against Six Beta2Glycoprotein-I-Related Peptides in the Antiphospholipid Syndrome. J Clin Immunol (2003) 23:377-83. doi: 10.1023/a:1025321617304

46. Meroni PL. Anti-Beta-2 Glycoprotein I Epitope Specificity: From Experimental Models to Diagnostic Tools. Lupus (2016) 25:905-10. doi: $10.1177 / 0961203316641772$

47. Tincani A, Morozzi G, Afeltra A, Alessandri C, Allegri F, Bistoni O, et al. Antiprothrombin Antibodies: A Comparative Analysis of Homemade and Commercial Methods. A Collaborative Study by the Forum Interdisciplinare Per La Ricerca Nelle Malattie Autoimmuni (FIRMA). Clin Exp Rheumatol (2007) 25:268-74.

48. Sciascia S, Sanna G, Murru V, Roccatello D, Khamashta MA, Bertolaccini ML. Anti-Prothrombin (aPT) and Anti-Phosphatidylserine/Prothrombin (aPS/ PT) Antibodies and the Risk of Thrombosis in the Antiphospholipid Syndrome. A Systematic Review. Thromb Haemost (2014) 111:354-64. doi: 10.1160/TH13-06-0509

49. Cattini MG, Bison E, Pontara E, Cheng C, Denas G, Pengo V. Tetra Positive Thrombotic Antiphospholipid Syndrome: Major Contribution of AntiPhosphatidyl-Serine/Prothrombin Antibodies to Lupus Anticoagulant Activity. J Thromb Haemost (2020) 18:1124-32. doi: 10.1111/jth.14765

50. Radin M, Foddai SG, Cecchi I, Rubini E, Schreiber K, Roccatello D, et al. Antiphosphatidylserine/Prothrombin Antibodies: An Update on Their Association With Clinical Manifestations of Antiphospholipid Syndrome. Thromb Haemost (2020) 120:592-8. doi: 10.1055/s-0040-1705115

51. Foddai SG, Radin M, Cecchi I, Gaito S, Orpheu G, Rubini E, et al. The Prevalence of Antiphospholipid Antibodies in Women With Late Pregnancy Complications and Low-Risk for Chromosomal Abnormalities. J Thromb Haemost (2020) 18:2921-8. doi: 10.1111/jth.15053

52. Pleguezuelo DE, Cabrera-Marante O, Abad M, Rodriguez-Frias EA, Naranjo L, Vazquez A, et al. Anti-Phosphatidylserine/Prothrombin Antibodies in Healthy Women With Unexplained Recurrent Pregnancy Loss. J Clin Med (2021) 10:2094. doi: 10.3390/jcm10102094

53. Sciascia S, Radin M, Cecchi I, Rubini E, Scotta A, Rolla R, et al. Reliability of Lupus Anticoagulant and Anti-Phosphatidylserine/Prothrombin Autoantibodies in Antiphospholipid Syndrome: A Multicenter Study. Front Immunol (2019) 10:376. doi: 10.3389/fimmu.2019.00376

54. Tebo AE, Jaskowski TD, Hill HR, Branch DW. Clinical Relevance of Multiple Antibody Specificity Testing in Anti-Phospholipid Syndrome and Recurrent Pregnancy Loss. Clin Exp Immunol (2008) 154:332-8. doi: 10.1111/j.13652249.2008.03774.x

55. Rand JH. Antiphospholipid Antibody-Mediated Disruption of the Annexin-V Antithrombotic Shield: A Thrombogenic Mechanism for the Antiphospholipid Syndrome. J Autoimmun (2000) 15:107-11. doi: 10.1006/ jaut. 2000.0410

56. Ieko M, Nakabayashi T, Takeda M, Naitoh S, Atsumi T, Koike T. The Inhibition of Protein C Anticoagulant Activity by Anti- $\beta 2$-Glycoprotein I ( $\beta 2$ gpi) Antibodies Isolated From Patients With Antiphospholipid Syndrome 
by Chromatography Methods. Mod Rheumatol (2002) 12:44-9. doi: 10.3109/ s101650200007

57. Merrill JT, Zhang HW, Shen C, Butman BT, Jeffries EP, Lahita RG, et al. Enhancement of Protein S Anticoagulant Function by Beta2-Glycoprotein I, A Major Target Antigen of Antiphospholipid Antibodies: Beta2-Glycoprotein I Interferes With Binding of Protein S to Its Plasma Inhibitor, C4b-Binding Protein. Thromb Haemost (1999) 81:748-57. doi: 10.1055/s-0037-1614566

58. Atsumi T, Khamashta MA, Ames PR, Ichikawa K, Koike T, Hughes GR. Effect of Beta 2glycoprotein I and Human Monoclonal Anticardiolipin Antibody on the Protein S/C4b-Binding Protein System. Lupus (1997) 6:358-64. doi: $10.1177 / 096120339700600403$

59. Staub HL, Bertolacci ML, Khamashta MA. Anti-Phosphatidylethanolamine Antibody, Thromboembolic Events and the Antiphospholipid Syndrome. Autoimmun Rev (2012) 12:230-4. doi: 10.1016/j.autrev.2012.07.008

60. Meroni PL, Biggioggero M, Pierangeli SS, Sheldon J, Zegers I, Borghi MO. Standardization of Autoantibody Testing: A Paradigm for Serology in Rheumatic Diseases. Nat Rev Rheumatol (2014) 10:35-43. doi: 10.1038/nrrheum.2013.180

61. Sciascia S, Willis R, Pengo V, Krilis S, Andrade D, Tektonidou MG, et al. The Comparison of Real World and Core Laboratory Antiphospholipid Antibody ELISA Results From Antiphospholipid Syndrome Alliance for Clinical Trials \& International Networking (APS ACTION) Clinical Database and Repository Analysis. Thromb Res (2019) 175:32-6. doi: 10.1016/j.thromres. 2019.01.010

62. Pregnolato F, Gerosa M, Raimondo MG, Comerio C, Bartoli F, Lonati PA, et al. EUREKA Algorithm Predicts Obstetric Risk and Response to Treatment in Women With Different Subsets of Anti-Phospholipid Antibodies. Rheumatology (Oxford) (2021) 60:1114-24. doi: 10.1093/rheumatology/keaa203

63. Monogioudi E, Martos G, Sheldon J, Meroni PL, Trapmann S, Zegers I. Development of a Certified Reference Material for Anti- $\beta 2$-Glycoprotein I IgG - Commutability Studies. Clin Chem Lab Med (2020) 59:325-32. doi: 10.1515/cclm-2020-0995

64. Chayoua W, Yin DM, Kelchtermans H, Moore GW, Gris JC, Musiał J, et al. Is There an Additional Value in Detecting Anticardiolipin and Anti- $\beta 2$ Glycoprotein I IgA Antibodies in the Antiphospholipid Syndrome? Thromb Haemost (2020) 120:1557-68. doi: 10.1055/s-0040-1714653

65. Chighizola CB, Raschi E, Banzato A, Borghi MO, Pengo V, Meroni PL. The Challenges of Lupus Anticoagulants. Expert Rev Hematol (2016) 9:389-400. doi: 10.1586/17474086.2016.1140034

66. Tonello M, Bison E, Cattini MG, Pontara E, Iaccarino L, Denas G, et al. AntiPhosphatidyl-Serine/Prothrombin Antibodies (aPS/PT) in Isolated Lupus Anticoagulant (LA): Is Their Presence Linked to Dual Test Positivity? Clin Chem Lab Med (2021). doi: 10.1515/cclm-2021-0692

67. Bevers EM, Galli M, Barbui T, Comfurius P, Zwaal RFA. Lupus anTicoagulant Igg's (LA) Are Not Directed to Phospholipids Only, But to a Complex of Lipid-Bound Human Prothrombin. Thromb Haemost (1991) 66:629-32. doi: 10.1055/s-0038-1646476

68. Roubey RAS, Pratt CW, Buyon JP, Winfield JB. Lupus Anticoagulant Activity of Autoimmune Antiphospholipid Antibodies Is Dependent Upon $\beta 2$ Glycoprotein I. J Clin Invest (1992) 90:1100-4. doi: 10.1172/JCI115926

69. Oosting JD, Derksen RHWM, Entjes HTI, Bouma BN, De Groot PG. Lupus Anticoagulant Activity Is Frequently Dependent on the Presence of $\beta 2$ Glycoprotein I. Thromb Haemost (1992) 67:499-502. doi: 10.155/s-0038-8480
70. Ruffatti A, Tonello M, Cavazzana A, Bagatella P, Pengo V. Laboratory Classification Categories and Pregnancy Outcome in Patients With Primary Antiphospholipid Syndrome Prescribed Antithrombotic Therapy. Thromb Res (2009) 123:482-7. doi: 10.1016/j.thromres.2008.03.012

71. Meroni PL, Borghi MO, Grossi C, Chighizola CB, Durigutto P, Tedesco F. Obstetric and Vascular Antiphospholipid Syndrome: Same Antibodies But Different Diseases? Nat Rev Rheumatol (2018) 14:433-40. doi: 10.1038/ s41584-018-0032-6

72. Agostinis C, Biffi S, Garrovo C, Durigutto P, Lorenzon A, Bek A, et al. In Vivo Distribution of $\beta 2$ Glycoprotein I Under Various Pathophysiologic Conditions. Blood (2011) 118:4231-8. doi: 10.1182/blood-2011-01-333617

73. Chighizola CB, Andreoli L, Gerosa M, Tincani A, Ruffatti A, Meroni PL. The Treatment of Anti-Phospholipid Syndrome: A Comprehensive Clinical Approach. J Autoimmun (2018) 90:1-27. doi: 10.1016/j.jaut.2018.02.003

74. Chatzidionysiou K, Samoli E, Sfikakis PP, Tektonidou MG. Effect of Belimumab Treatment on Antiphospholipid Antibody Levels: Post-Hoc Analysis Based on Two Randomised Placebo- Controlled Trials in Systemic Lupus Erythematosus. Ann Rheumatol Dis (2020) 79:304-7. doi: 10.1136/ annrheumdis-2019-216367

75. Nuri E, Taraborelli M, Andreoli L, Tonello M, Gerosa M, Calligaro A, et al. Long-Term Use of Hydroxychloroquine Reduces Antiphospholipid Antibodies Levels in Patients With Primary Antiphospholipid Syndrome. Immunol Res (2017) 65:17-24. doi: 10.1007/s12026-016-8812-Z

76. Bettiol A, Pregnolato F, Sciascia S, Emmi G, Prisco D, Meroni PL. Association of Subcutaneous Belimumab and Long-Term Antimalarial Treatment Reduces Antiphospholipid Antibodies Levels in Systemic Lupus Erythematosus: Post-Hoc Analysis of a Randomised Placebo-Controlled Trial-Comment on: 'Effect of Belimumab Treatment on Antiphospholipid Antibody Levels: Post-Hoc Analysis Based on Two Randomised PlaceboControlled Trials in Systemic Lupus Erythematosus' by Chatzidionysiou Et al. Ann Rheumatol Dis (2020). doi: 10.1136/annrheumdis-2020-218377. annrheumdis-2020-218377

77. Mendoza-Pinto C, García-Carrasco M, Cervera R. Role of Infectious Diseases in the Antiphospholipid Syndrome (Including Its Catastrophic Variant). Curr Rheumatol Rep (2018) 20:62. doi: 10.1007/s11926-018-0773-x

Conflict of Interest: The authors declare that the research was conducted in the absence of any commercial or financial relationships that could be construed as a potential conflict of interest.

Publisher's Note: All claims expressed in this article are solely those of the authors and do not necessarily represent those of their affiliated organizations, or those of the publisher, the editors and the reviewers. Any product that may be evaluated in this article, or claim that may be made by its manufacturer, is not guaranteed or endorsed by the publisher.

Copyright $\odot 2021$ Meroni and Borghi. This is an open-access article distributed under the terms of the Creative Commons Attribution License (CC BY). The use, distribution or reproduction in other forums is permitted, provided the original author(s) and the copyright owner(s) are credited and that the original publication in this journal is cited, in accordance with accepted academic practice. No use, distribution or reproduction is permitted which does not comply with these terms. 